University of Nebraska - Lincoln

DigitalCommons@University of Nebraska - Lincoln

Faculty Papers and Publications in Animal

Science

Animal Science Department

1985

\title{
Effect of Source of Dietary Energy and Energy Restriction During Lactation on Sow and Litter Performance
}

J. L. Nelsson

Kansas State University

A. J. Lewis

University of Nebraska-Lincoln, alewis2@unl.edu

E. R. Peo, Jr.

University of Nebraska-Lincoln

B. D. Moser

University of Missouri

Follow this and additional works at: https://digitalcommons.unl.edu/animalscifacpub

Part of the Animal Sciences Commons

Nelsson, J. L.; Lewis, A. J.; Peo, Jr., E. R.; and Moser, B. D., "Effect of Source of Dietary Energy and Energy Restriction During Lactation on Sow and Litter Performance" (1985). Faculty Papers and Publications in Animal Science. 673.

https://digitalcommons.unl.edu/animalscifacpub/673

This Article is brought to you for free and open access by the Animal Science Department at DigitalCommons@University of Nebraska - Lincoln. It has been accepted for inclusion in Faculty Papers and Publications in Animal Science by an authorized administrator of DigitalCommons@University of Nebraska - Lincoln. 


\title{
EFFECT OF SOURCE OF DIETARY ENERGY AND ENERGY RESTRICTION DURING LACTATION ON SOW AND LITTER PERFORMANCE ${ }^{1,2}$
}

\author{
J. L. Nelssen ${ }^{3}$, A. J. Lewis ${ }^{4}$, E. R. Peo, Jr. and B. D. Moser ${ }^{5}$ \\ University of Nebraska ${ }^{6}$, \\ Lincoln 68583-0908
}

\section{Summary}

The effects of source of energy and energy restriction during lactation on sow and litter performance were investigated in an experiment with 90 primiparous sows. At parturition, the sows were randomly assigned to diets containing either tallow or cornstarch as a major energy source. Energy intake was restricted to $8 \mathrm{Mcal}$ of metabolizable energy $\cdot$ sow $^{-1} \cdot \mathrm{d}^{-1}$ during a 28-d lactation. All sows received equal amounts of crude protein, vitamins and minerals daily, which met or exceeded standard recommendations. Sows fed the diet with tallow lost more weight $(\mathrm{P}<.05)$ during lactation than those fed the diet with cornstarch. Litter size at $d 28$ was greater $(\mathrm{P}<.07)$ for sows fed cornstarch than for sows fed tallow. However, pig and litter weights on d 14 and 28 of lactation were similar between dietary treatments. Sows were bled on d 110 of gestation and d 14 and 28 of lactation and blood plasma was analyzed for urea. A significant treatment $x$ time interaction was found for plasma urea. Sows fed the diet with tallow appeared to catabolize more protein than those fed the diet with cornstarch. Energy digestibility was lower $(P<.01)$ in the diet containing tallow, but protein digestibility was not affected by source of energy. Percentages of sows in estrus by 7,14 and $70 \mathrm{~d}$ post-

\footnotetext{
'Published as Paper No. 7421, Journal Series, Nebraska Agr. Exp. Sta. Research reported was conducted under Project 13-011.

${ }^{2}$ The technical assistance of Mary B. Barnes is gratefully acknowledged.

${ }^{3}$ Present address: Dept. of Anim. Sci. and Industry, Kansas State Univ., Manhattan 66506.

${ }^{4}$ To whom reprint requests should be addressed.

${ }^{5}$ Present address: Dept. of Anim. Sci., Univ. of Missouri, Columbia 65211.

${ }^{6}$ Dept. of Anim. Sci.

Received March 5, 1984

Accepted September 16, 1984 .
}

weaning were not different between treatments. (Key Words: Primiparous Sows, Tallow, Cornstarch, Lactation, Performance, Estrus.)

\section{Introduction}

In numerous experiments, the addition of fat to the diets of poultry has improved feed efficiency more than expected from the increase in the metabolizable energy (ME) content of the diet (Sibbald et al., 1962; Vermeersch and Vanschoubroek, 1968; Jensen et al., 1970; Gomez and Polin, 1974; Whitehead and Fisher, 1975). This response has been referred to as an "extracaloric" effect of fat. Sell and Mateos (1981) have summarized the cause(s) of the extracaloric effect as (1) a synergistic interaction among dietary fats conducive to increased utilization of dietary lipids and(or) (2) an interaction between supplemental fat and nonlipid dietary constituents that results in improved dietary energy utilization.

Recently, much attention has been given to the addition of fat to sow diets during late gestation and early lactation in an attempt to improve the survival of newborn pigs (Moser and Lewis, 1980; Pettigrew, 1981). Although the data are not conclusive, there is evidence that the addition of fat to sow diets confers advantages, in terms of pig survival, that are not conferred by equal additions of ME from other sources.

The objective of the present experiment was to compare fat and carbohydrate as dietary energy sources for lactating primiparous sows.

\section{Experimental Procedure}

Ninety primiparous sows (Landrace $\times$ Large White $\times$ Duroc $\times$ Hampshire) were fed 1.8 $\mathrm{kg} \cdot \operatorname{sow}^{-1} \cdot \mathrm{d}^{-1}$ of a $14 \%$ crude protein gestation diet (table 1) until d 108 of gestation. On d 108 , the sows were moved into farrowing crates and were fed $2.27 \mathrm{~kg} / \mathrm{d}$ of a gestation diet 
TABLE 1. COMPOSITION OF GESTATION AND LACTATION DIETS (G/D)

\begin{tabular}{|c|c|c|c|c|}
\hline \multirow[b]{2}{*}{ Ingredientc } & \multicolumn{2}{|c|}{ Gestation $\operatorname{diet}^{\mathrm{a}}$} & \multicolumn{2}{|c|}{ Lactation $\operatorname{diet}^{b}$} \\
\hline & Standard & With tallowe & Tallow & Cornstarch \\
\hline $\begin{array}{l}\text { Cornstarch (IFN 4-02-889)f } \\
\text { Tallow, bleachable fancy (IFN 4-07-880) }\end{array}$ & & 68 & 415 & 869 \\
\hline Corn (IFN 4-02-992) & 1,087 & 1,105 & & \\
\hline $\begin{array}{l}\text { Soybean meal (IFN 5-04-604) } \\
\text { Beet pulp (IFN 4-00-669) }\end{array}$ & $\begin{array}{l}280 \\
360\end{array}$ & $\begin{array}{l}511 \\
454\end{array}$ & 1,343 & 1,343 \\
\hline Wheat bran (IFN 4-08-554) & & & 227 & 227 \\
\hline Limestone (1FN 6-02-632) & 4 & & 39 & 39 \\
\hline Dicalcium phosphate (IFN 6-01-080) & 41 & 96 & 74 & 74 \\
\hline Salt (IFN 6-04-151) & 9 & 11 & 23 & 23 \\
\hline Trace mineral mix ${ }^{h}$ & 1 & 1 & 5 & 5 \\
\hline Vitamin mix & 18 & 23 & 45 & 45 \\
\hline Selenium premix $\mathrm{j}$ & & 1 & 2 & 2 \\
\hline Chromic oxide ${ }^{k}$ & & & 11 & 13 \\
\hline Total feed/d & 1,800 & 2,270 & 2,184 & 2,640 \\
\hline
\end{tabular}

${ }^{a}$ Standard diet fed through $\mathrm{d} 108$ of gestation and during the postweaning period. Diet with tallow fed from d 108 to farrowing.

${ }^{b}$ Fed to provide the following amounts $(g / d)$ of protein, $\mathrm{Ca}$ and $P$ during lactation: 625,36 and 24 , respectively.

${ }^{\mathrm{c}}$ The following ME values $(\mathrm{kcal} / \mathrm{kg}$ ) were assumed: cornstarch, 3,688; tallow, 7,716; corn, 3,417; soybean meal, 3,086; beet pulp, 2,646; wheat bran, 2,326.

${ }^{d}$ Contributed the following amounts $(\mathrm{g} / \mathrm{d}$ ) of protein, $\mathrm{Ca}$ and $\mathrm{P}$ during gestation: $254,14.5$ and 12.5 , respectively. Provided 5.4 Mcal of $\mathrm{ME} \cdot \mathrm{sow}^{-1} \cdot \mathrm{d}^{-1}$ during gestation.

${ }^{e}$ Contributed the following amounts $(\mathrm{g} / \mathrm{d})$ of protein, $\mathrm{Ca}$ and $\mathrm{P}$ during gestation: 363,27 and 24 , respectively. Provided 7.1 Mcal of $\mathrm{ME} \cdot$ sow $\mathrm{w}^{-1} \cdot \mathrm{d}^{-1}$ during gestation.

f "Buffalo" brand cornstarch, Corn Products Co., Englewood Cliffs, NJ 07632.

B National By-Products Inc., Bellevue, NE 68005. Stabilized with .05\% "Tenox 2" (Eastman Kodak Co., Rochester, NJ 14650) contains $20 \%$ butylated hydroxyanisole, $6 \%$ propyl gallate, $4 \%$ citric acid and $70 \%$ propylene glycol.

${ }^{h}$ Percentage composition was $\mathrm{Zn}, 20 ; \mathrm{Fe}, 10 ; \mathrm{Mn}, 5.5 ; \mathrm{Cu}, 1.1 ; \mathrm{I}, .15$.

${ }^{i}$ Composition per kg of premix: vitamin A (stabilized), 2,750,000 IU; vitamin $D_{3}$ (stabilized), 220,000 IU; riboflavin, 1,450 $\mathrm{mg}$; d-pantothenic acid, $11,000 \mathrm{mg}$; niacin, 11,000 $\mathrm{mg}$; choline chloride, 110,000 mg; vitamin $B_{12}, 11 \mathrm{mg}$; menadione sodium bisulfite, 1,100 $\mathrm{mg}$; ethoxyquin, $2.2 \mathrm{~g}$; vitamin $\mathrm{E}, 11,000 \mathrm{IU}$.

$\mathrm{j}_{\text {Percentage composition was } \mathrm{Se}, .02 .}$

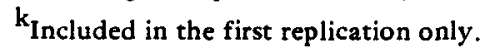

containing $3 \%$ stabilized tallow (table 1 ) until parturition. The sows farrowed in April, June and September 1981 (replications 1, 2 and 3, respectively). At parturition they were randomly assigned to diets containing either stabilized tallow or cornstarch as a major energy source. The sows were fed the experimental diets during a 28-d lactation period. To permit an adequate comparison of energy sources, total energy intake must be restricted, therefore sows were fed $8 \mathrm{Mcal}$ of $M E \cdot \operatorname{sow}^{-1} \cdot \mathrm{d}^{-1}$ during lactation (table 1 ). This energy intake has been shown to be in the region in which the performance of primiparous sows and their litters will respond to improve- ments in dietary energy status (Reese et al. 1982a). One-half of the daily feed allowance was given during the morning and one-half in the afternoon. In the diet containing tallow, $40 \%$ of the energy content was from the added fat; there was no added fat in the diet containing cornstarch. For the first replication, .5\% chromic oxide was included in both lactation diets to serve as a marker to determine apparent energy and protein digestibilities. All sows received the same daily allowances of protein, vitamins and minerals, which met or exceeded the recommendations of the NRC (1979).

On d 110 of gestation the average backfat thickness of sows was measured ultrasonically. 
In addition, a sample of venous blood was collected from the brachial region in a heparinized tube. Blood samples were placed in an ice bath immediately after collection and were. stored at $4 \mathrm{C}$ before centrifugation $(1,400 \times \mathrm{g}$ for $20 \mathrm{~min}$, at $2 \mathrm{C}$ ) to separate plasma. Plasma samples were stored at $-20 \mathrm{C}$ until analyzed for urea. Urea concentration was determined by the automated procedure described by Marsh et al. (1965).

Sows and pigs were weighed within $24 \mathrm{~h}$ after parturition. Litter size was equalized within each pair of sows assigned to the two diets until $3 \mathrm{~d}$ after parturition. Thus average litter size at $\mathrm{d} 3$ was equal for the two treatments (9.6 pigs), but there were differences between different pairs of sows. Creep feed was not available to pigs at any time. On d 14 and 28 of lactation, sows and pigs were weighed and blood samples were collected from sows as described previously. Backfat thickness of sows was also measured on $d 14$ and 28 of lactation. Feces samples were obtained from each sow in the first replication $(n=25)$ for three consecutive days during $\mathrm{d} 21$ to 25 of lactation. The feces samples were obtained by rectal stimulation $2 \mathrm{~h}$ after the morning feeding, and the samples from each sow for the 3-d collection period were pooled and frozen until subsequent analysis. Samples of the diets were also collected and frozen until analyzed.

Feed and feces samples were analyzed for dry matter, energy, $\mathrm{N}$ and $\mathrm{Cr}$. Energy was determined using an adiabatic oxygen bomb calorimeter as described by the Parr Instrument Company (1978). The $\mathrm{N}$ content was determined by the Kjeldahl method using procedures similar to those described by AOAC (1980). Chromium concentration was determined by atomic absorption spectrophotometry (Williams et al., 1962). Indirect estimates of apparent energy and protein digestibilities of experimental diets were calculated according to methods described by Lindahl (1959).

After weaning, sows were moved into individual gestation stalls and fed 1.8 $\mathrm{kg} \cdot \mathrm{sow}^{-1} \cdot \mathrm{d}^{-1}$ of the gestation diet. They were moved to a pen containing a boar once daily to check for estrus. A sow was considered to be in estrus when she stood to be mounted by a boar on two consecutive days. There were no sows that stood for a boar for one day only. Estrous tests were continued in sows that had not previously exhibited estrus for a maximum of $70 \mathrm{~d}$ postweaning. Beginning on $\mathrm{d} 15$ post- weaning and weekly thereafter, any sow that had not been detected in estrus was bled for progesterone analysis. Serum progesterone was determined by the method of Anthony et al. (1981). The progesterone concentrations were used to indicate possible luteal tissue activity on ovaries of sows that had not been detected in estrus. A serum progesterone concentration of $>5 \mathrm{ng} / \mathrm{ml}$ was considered to be indicative of the presence of luteal tissue on the ovary. Thus, any sow with a progesterone concentration $>5$ $\mathrm{ng} / \mathrm{ml}$ was assumed to have either exhibited behavioral estrus that was not detected or had ovulated in the absence of estrus.

Dietary effects on sow weight change and backfat change were tested using least-squares analysis of covariance (SAS, 1979; Steel and Torrie, 1980). Covariates included backfat thickness on d 110 of gestation, postpartum sow weight and litter size $3 \mathrm{~d}$ postpartum. Covariates for pig performance analysis included only litter size $3 \mathrm{~d}$ postpartum. The statistical model included replication to remove any effects due to season in which the sows farrowed. Plasma urea concentration was tested using a split-plot analysis with energy source as the whole unit and bleeding times as the subunit (SAS, 1979; Steel and Torrie, 1980). Because the occurrence of estrus (or no estrus) is a categorical response variable rather than a continuous variable, a statistical model for categorical data (Grizzle et al., 1969) was used to test days to estrus postweaning.

\section{Results and Discussion}

The effect of energy source during lactation on sow performance is shown in table 2. Also included in table 2 are the significance levels of the covariates used in the analysis. Sows fed the diet with tallow lost more $(\mathrm{P}<.01)$ weight during $\mathrm{d} 0$ to 14 of lactation than those fed the diet with cornstarch. Subsequent weight loss (d 14 to 28 ) was similar between the two treatments, but overall, sows fed the diet with tallow lost more $(\mathrm{P}<.05)$ weight during the 28 $\mathrm{d}$ of lactation. Backfat losses were high regardless of treatment. Sows fed tallow tended to lose more backfat than those fed cornstarch, but the differences were not significant $(P>$ $.50)$.

Tallow was included in diets of all sows during late gestation to allow their digestive systems to adjust to dietary lipid before feeding the lactation diets. The adjustment period was, 


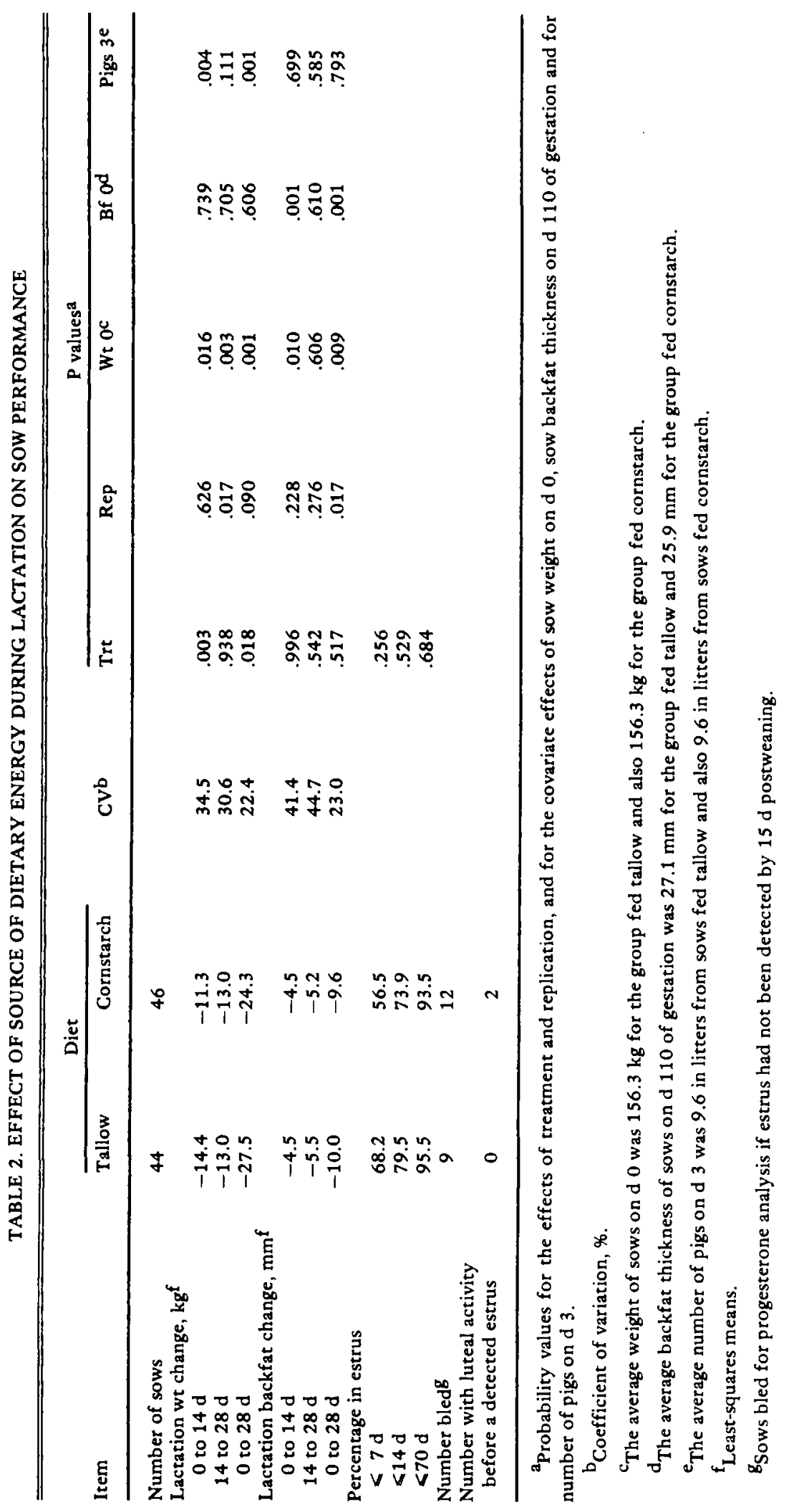


however, relatively short ( $6 \mathrm{~d}$ ), and one reason for the greater weight loss of sows fed the diet containing tallow may have been poor digestion of the tallow, as indicated by the digestibility data. Additionally, feeding fat has been shown to increase the lipid content of sows' milk (Seerley et al., 1974; Coffey et al., 1982; Lellis and Speer, 1983). Thus, a preferential shunting of fatty acids directly to mammary glands to serve as a component of milk is possible. With a restricted intake of energy during lactation, this shunting of energetic substrates directly to milk would result in an increased weight loss of sows fed tallow. The numerical increase in backfat loss of sows fed tallow lends support to the hypothesis (Reese et al., 1982a) of an increased dependence on body fat by sows fed tallow in order to continue to lactate under conditions of severe energy restriction.

The effects of energy source on pig performance are presented in table 3 . There was no difference $(\mathrm{P}>.25)$ in average pig weight on either d 14 or 28 of lactation. Likewise, litter weights on $\mathrm{d} 14$ and 28 were similar between dietary treatments. Thus, although sows fed tallow lost more body weight than those fed cornstarch, there was no concurrent decrease in litter weight at weaning. There was no difference $(P>.25)$ in litter size on d 14 of lactation, but litter size on d 28 was higher for pigs from sows fed cornstarch.

Several previous reports have noted that pig survival was improved when fat was included in sow diets during late gestation and early lactation (Moser and Lewis, 1980; Pettigrew, 1981). However, in the present experiment, litter size was standardized until d 3 after parturition. Therefore, the critical period, during which the greatest losses of pigs occur (Hutchinson et al., 1954; Fahmy and Bernard, 1971), was not included. In the present experiment intakes were isocaloric, unlike many experiments in which energy intake was increased by the addition of fat. Furthermore, the addition of lipid to sow diets has not always been found to be superior to the addition of other forms of dietary energy. Boyd et al. (1978) found a tendency for higher survival of pigs from sows fed cornstarch during late gestation than from sows fed tallow when intakes were isocaloric. These researchers reported that additional energy in late gestation in the form of either tallow or cornstarch increased milk fat concentration. Milk yield and(or) milk composition has been improved by addition of lipids to sow

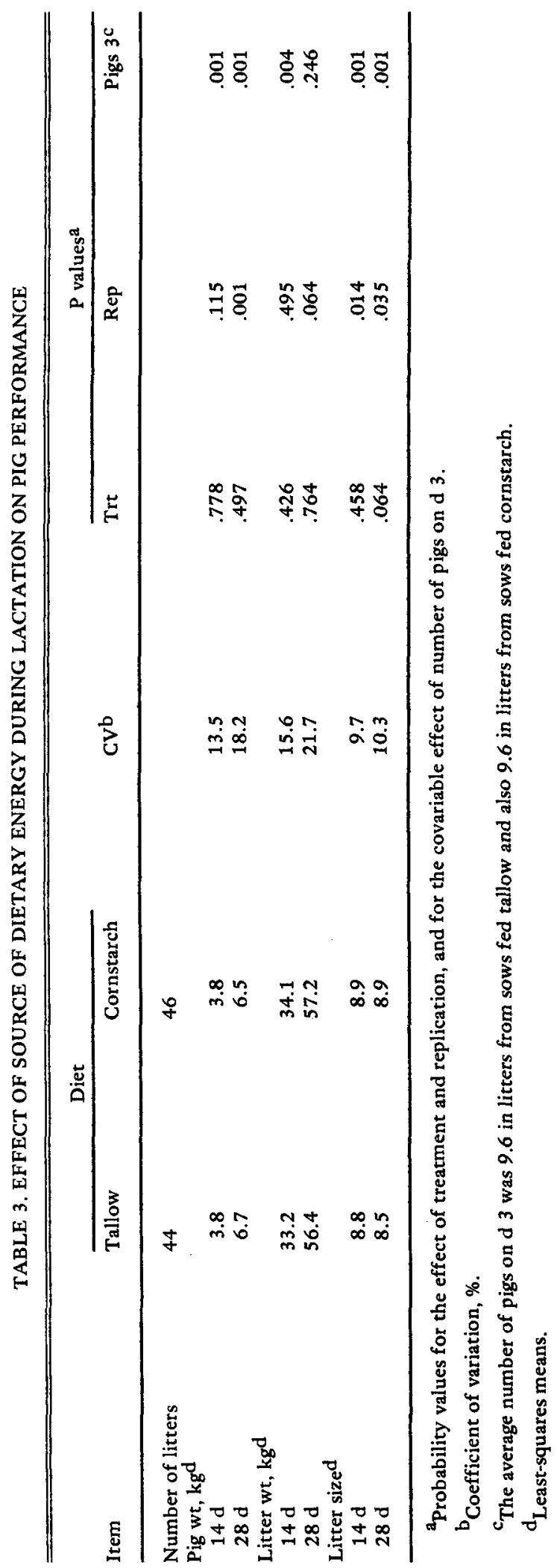




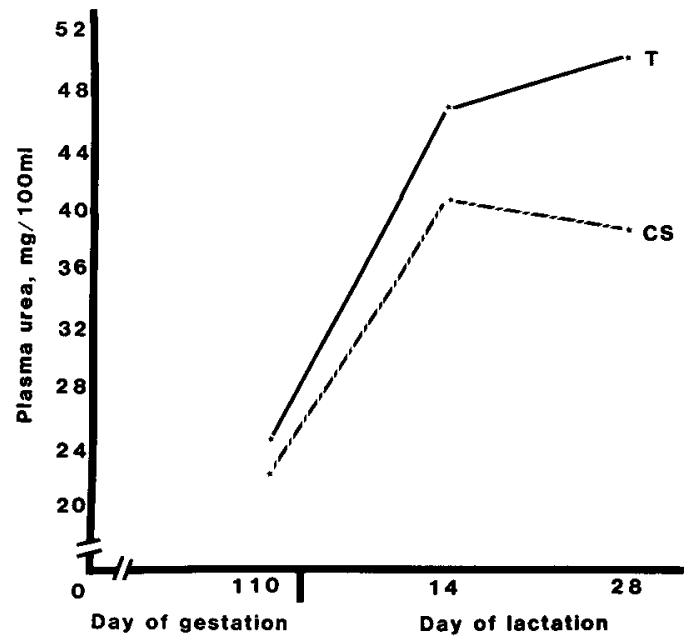

Figure 1. Plasma urea concentrations of primiparous sows in late gestation and lactation. Sows were fed diets containing either tallow (T) or cornstarch (CS). Treatment effect ( $T$ vs $C S$ ), $P<.001$. Treatment $X$ time interaction, $\mathrm{P}<.001$.

diets in other research (Friend, 1974; Kruse et al., 1977; Coffey et al., 1982).

Various seasonal (replication) effects were observed as indicated by the probability values listed in tables 2 and 3 . Sows that farrowed in September lost less weight, but more backfat, and weaned lighter weight pigs than sows that farrowed in either April or June.

Plasma urea concentrations are shown in figure 1. The figure illustrates a time $x$ diet interaction $(\mathrm{P}<.001)$. The plasma urea concentrations of both groups of sows increased between $\mathrm{d} 110$ of gestation and d 14 of lactation. However, urea concentrations of sows fed cornstarch fell slightly from d 14 to d 28, whereas urea concentrations of sows fed tallow continued to increase. Plasma urea concentrations provide an index of the extent of catabolism of amino acids. Thus, these data indicate that catabolism was more extensive in sows fed tallow than in sows fed cornstarch. The data do not distinguish between whether the additional amino acids catabolized by sows fed tallow were derived from dietary or endogenous protein. Glucose is needed for lactose synthesis by mammary tissues, and there is a considerable need for gluconeogenesis when feed intake is restricted during lactation. Because free fatty acids cannot be utilized as a glucogenic substrate, sows fed tallow would be more dependent on amino acids as a source of glucose than sows fed cornstarch. Therefore, the apparently greater amino acid degradation by sows fed tallow probably occurred in part because of less substrate contribution from dietary sources for lactose synthesis.

Energy digestibility of the diet containing tallow was lower $(\mathrm{P}<.001)$ than that of the diet with cornstarch (table 4). This reduction in available energy for sows that received tallow diets is probably one reason why these sows lost more weight and apparently catabolized more amino acids. Addition of fat to diets of growing pigs usually increases energy digestibility (Greeley et al., 1964; Tribble, 1975; Keaschall et al., 1983). Protein digestibility was similar for both diets. This finding is in contrast to the improvement in protein digestiblity that has been reported when fat was added to growing-finishing diets (Keaschall et al., 1983).

Evidently, the replacement of cornstarch by tallow offered no advantage in terms of sow performance during lactation. There was certainly no extracaloric effect on energy digestibility as observed in experiments with poultry. In experiments with laying hens,

TABLE 4. EFFECT OF SOURCE OF DIETARY ENERGY DURING LACTATION ON DIGESTIBILITIES OF ENERGY AND PROTEIN

\begin{tabular}{lllll}
\hline & & Diet & & P value \\
Item & Tallow & Cornstarch & CVa & trt $^{\text {b }}$ \\
\hline Number of sows & 13 & 12 & & \\
Energy digestibility, \%c & 78.9 & 85.2 & 2.5 & .001 \\
Protein digestibility, \%c & 86.3 & 85.9 & 2.1 & .572 \\
\hline
\end{tabular}

\footnotetext{
${ }^{\mathrm{a}}$ Coefficient of variation, $\%$.

${ }^{\mathrm{b}}$ Probability value for the effect of treatment.

cLeast-squares means.
} 
Mateos and Sell (1980a) found that the extracaloric effect of yellow grease was most prominent at low levels of fat inclusion and decreased linearly as level of fat increased. In turkeys, fat supplementation has been found to slow rate of passage (Duke and Evanson, 1972). Thus, fat should have a major influence on any ingredient that passes through the gastrointestinal tract at a rate too rapid for maximal absorption. The higher energy digestiblity of cornstarch diets may have been caused by a slower rate of passage of this ingredient than that of other semipurified carbohydrate sources such as sucrose and maltose (Mateos and Sell, 1980b). A relatively high level of tallow ( $19 \%$ of the diet) was added in the present experiment.

The percentage of sows in estrus by 7,14 and $70 \mathrm{~d}$ postweaning was not affected by source of energy (table 2). The low energy intake $(8 \mathrm{Mcal} / \mathrm{d})$ resulted in a delayed return to estrus postweaning in both groups. A similar delay in first postweaning estrus of primiparous sows fed a low energy intake during lactation has been reported by Reese et al. (1982a,b). When fed an adequate energy intake (16 $\mathrm{Mcal} / \mathrm{d}$ ) during lactation, approximately $95 \%$ of primiparous sows exhibited estrus within $7 \mathrm{~d}$ after weaning (Reese et al., 1982a).

Two sows fed the diet with cornstarch that were not detected in estrus by $15 \mathrm{~d}$ postweaning were found to have serum progesterone concentrations $>5 \mathrm{ng} / \mathrm{ml}$. This was considered to indicate the presence of luteal tissue activity. These sows either exhibited behavioral estrus that was not detected when exposed to a boar once daily or they had ovulated in the absence of estrus. If these two sows had been included in the category of returning to estrus, the percentage of sows fed cornstarch that were in estrus by 7,14 and 70 would have been 60.9 , 78.3 and 97.8 , respectively.

In this experiment, in which primiparous sows were fed a restricted energy intake during lactation, replacement of cornstarch with tallow was not beneficial. Unlike the situation in poultry where an extracaloric effect of fat has been reported, replacement of carbohydrate by fat on an isocaloric ME basis did not improve the lactational performance of sows fed a low level of energy intake.

\section{Literature Cited}

Anthony, R. V., R. J. Kittok, E. F. Ellington and M. K. Nielsen. 1981. Effects of zeranol on growth and ease of calf delivery in beef heifers. J. Anim. Sci. 53:1325.
AOAC. 1980, Official Methods of Analysis (13th Ed.). Association of Official Analytical Chemists, Washington, DC.

Boyd, R. D., B. D. Moser, E. R. Peo, Jr. and P. J. Cunningham. 1978. Effect of energy source prior to parturition and during lactation on piglet survival and growth and on milk lipids. J. Anim. Sci. $47: 883$.

Coffey, M. T., R. W. Seerley and J. W. Mabry. 1982. The effect of source of supplemental dietary energy on sow milk yield, milk composition and litter performance. J. Anim. Sci. 55:1388.

Duke, G. E. and O. A. Evanson. 1972. Inhibition of gastric motility by duodenal contents in turkeys. Poul. Sci. 51:1625.

Fahmy, M. H, and C. Bernard. 1971. Causes of mortality in Yorkshire pigs from birth to 20 weeks of age. Can. J. Anim. Sci. 51:351.

Friend, D. W. 1974. Effect on the performance of pigs from birth to market weight of adding fat to the lactation diet of their dams. J. Anim. Sci. 39: 1073.

Gomez, M. X. and D. Polin. 1974. Influence of cholic acid on the utilization of fats in the growing chicken. Poul. Sci. 53:773.

Greeley, M. G., R. J. Meade and L. E. Hanson. 1964. Energy and protein intakes by growing swine. I. Effects on rate and efficiency of gain and on nutrient digestibility. J. Anim. Sci. 23:808.

Grizzle, J. E., C. F. Starmer and G. G. Koch. 1969. Analysis of categorical data by linear models. Biometrics 25:489.

Hutchinson, H. D., S. W. Terrill, C. C. Morrill, H. W. Norton, R. J. Meade, A. H. Jensen and D. E. Becker. 1954. Causes of baby pig mortality. J. Anim. Sci. 13:1023 (Abstr.).

Jensen, L. S., G. W. Schumaier and J. D. Latshaw. 1970. "Extra caloric" effect of dietary fat for developing turkeys as influenced by calorieprotein ratio. Poul. Sci. 49:1697.

Keaschall, K. E., B. D. Moser, E. R. Peo, Jr., A. J Lewis and T. D. Crenshaw. 1983. "Dried fat" for growing-finishing swine. J. Anim. Sci. 56:286.

Kruse, P. E., V. Danielsen, H. E. Nielsen and K. Christensen. 1977. The influence of different dietary levels of linoleic acid on reproductive performance and fatty acid composition of milk fat and plasma lipids in pigs. Acta Agr. Scand. $27: 289$.

Lellis, W. A. and V. C. Speer. 1983. Nutrient balance of lactating sows fed supplemental tallow. J. Anim. Sci. 56:1334.

Lindahl, I. L. 1959. Methods employed in nutrition research. In: Techniques and Procedures in Animal Production Research. pp 173-193. (Monogr.) Amer. Soc. Anim. Prod., Champaign, IL.

Marsh, W. H., B. Fingerhut and H. Miller. 1965. Automated and manual direct methods for the determination of blood urea. Clin. Chem. 11:624.

Mateos, G. G. and J. L. Sell. 1980a. True and apparent metabolizable energy value of fat for laying hens: Influence of level of use. Poul. Sci. 59:369.

Mateos, G. G. and J. L. Sell. 1980b. Influence of graded levels of fat on utilization of pure carbohydrate by the laying hen. J. Nutr. 110:1894.

Moser, B. D. and A. J. Lewis. 1980 . Adding fat to sow 
diets - An update. Feedstuffs 52(9): 36 .

NRC. 1979. Nutrient Requirements of Domestic Animals, No. 2. Nutrient Requirements of Swine. Eighth Revised Ed. National Academy of Sciences - National Research Council, Washington, DC.

Parr Instrument Company. 1978. Instructions for the 1241 and 1242 adiabatic calorimeters. Manual No. 153. Parr Instrument Co., Moline, IL.

Pettigrew, J. E., Jr. 1981. Supplemental dietary fat for peripartal sows: A review. J. Anim. Sci. 53:107.

Reese, D. E., B. D. Moser, E. R. Peo, Jr., A. J. Lewis, D. R. Zimmerman, J. E. Kinder and W. W. Stroup. 1982a. Influence of energy intake during lactation on the interval from weaning to first estrus in sows. J. Anim. Sci. 5 5:590.

Reese, D. E., B. D. Moser, E. R. Peo, Jr., A. J. Lewis, D. R. Zimmerman, J. E. Kinder and W. W. Stroup. $1982 \mathrm{~b}$. Influence of energy intake during lactation on subsequent gestation, lactation and postweaning performance of sows. J. Anim. Sci. 55:867.

SAS. 1979. SAS User's Guide. Statistical Analysis System Institute, Inc., Cary, NC.

Seerley, R. W., T. A. Pace, C. W. Foley and R. D. Scarth. 1974. Effect of energy intake prior to parturition on milk lipids and survival rate, thermostability and carcass composition of piglets. J. Anim. Sci. 38:64.
Sell, J. L. and G. G. Mateos. 1981. Influence of supplemental fat on utilization of dietary energy and rate of food passage in poultry. Proc. Georgia Nutr. Conf. Univ. of Georgia, Athens. pp 161176.

Sibbald, I. R., S. J. Slinger and W. F. Pepper. 1962. The responses of chicks to the dietary inclusion of materials which might be assumed to possess beneficial extra-caloric properties. Poul. Sci. 41:1254.

Steel, R.G.D. and J. H. Torrie. 1980. Principles and Procedures of Statistics (2nd Ed.). McGraw-Hill Book Co., New York.

Tribble, L. F. 1975. The effects of added fat in sorghum-soybean meal rations. Texas Tech Univ. Swine Rep. pp 25-28.

Vermeersch, G. and F. Vanschoubroek. 1968. The quantification of the effect of increasing levels of various fats on body weight gain, efficiency of food conversion and food intake of growing chicks. Brit. Poul. Sci. 9:13.

Whitehead, C. C. and C. Fisher. 1975. The utilisation of various fats by turkeys of different ages. Brit. Poul. Sci. 16:481.

Williams, C. H., D. J. David and O. Iismaa. 1962. The determination of chromic oxide in faeces samples by atomic absorption spectrophotometry. J. Agr. Sci. (Camb.) 59:381. 